Józef Maślanka ${ }^{1}$

\title{
Restoration of Boundary Markers and the Determination of Boundary Points - Proposed Amendments to the Laws of Poland ${ }^{2}$
}

\begin{abstract}
The article presents proposed amendments to the provisions of the Polish Geodetic and Cartographic Law regarding the restoration of boundary markers and the determination of boundary points of cadastral parcels. The current legal regulations are both insufficient and ambiguous, which results in significant and harmful discrepancies both in the interpretation of the legislation and its application. As a result, the database of the register of land and buildings (EGiB), which keeps the records on the boundaries of cadastral parcels and the attributes of boundary points describing these boundaries, frequently does not correspond to the actual status and is therefore unreliable. Due to the importance of this data, and of the entire EGiB database, to the socio-economic system of the country, this should no longer be tolerated. In this research paper, the author highlights the problems both relating to the legal regulations on the procedure as well as to the content of the database of the register of land and buildings. In both cases, the defects carry consequences that are adverse for the quality of the EGiB data and contribute to the loss of their reliability The specific amendments to the legislation proposed in this article are to prevent the further misinterpretation and misapplication of the current legal provisions and should allow to meet the reasonable expectations and needs of the users of the data contained in the register of land and buildings, especially property owners.
\end{abstract}

Keywords: cadastre, register of land and buildings, parcel boundaries, boundary points

Received: 3 June 2019; accepted: 30 September 2019

(C) 2020 Author. This is an open access publication, which can be used, distributed and reproduced in any medium according to the Creative Commons CC-BY 4.0 License.

1 AGH University of Science and Technology, Faculty of Mining Surveying and Environmental Engineering, Krakow, Poland, email podwilk@agh.edu.pl

ORCID ID: https://orcid.org/0000-0002-7317-0292

2 The article was prepared under the research subvention of AGH University of Science and Technology No. 16.16.150.545 in 2019 


\section{Introduction}

The issues concerning the restoration of boundary markers and the determination of boundary points are regulated in Poland by the Act of 17 May 1989 - Geodetic and Cartographic Law [1] (hereinafter referred to as "PGiK"). The technical and geodetic aspects of the implementation of the material and technical procedures mentioned above, as well as the detailed content of the prepared documents are set out in the secondary legislation to the Geodetic and Cartographic Law in the form of the regulation of 9 November 2011 on technical standards (abbreviated name) [2]. On the other hand, the manner of recording and updating the data on cadastral parcels and boundary points in the register of land and buildings (hereinafter abbreviated as "EGiB") is specified in the Regulation of 29 March 2001 on the register of lands and buildings [3].

The EGiB database deserves special attention, as e.g. recording the results of surveying works relating to the register of land and buildings makes it a source of the data for many other public registers in Poland, listed in Article 21 of the Geodetic and Cartographic Law (including land and mortgage registers, tax system, spatial planning), as well as for administrative and court proceedings. Possible defects and deficiencies occurring in the database are therefore propagated to the above-mentioned registers and to formal and legal procedures, sometimes resulting in very serious damage which is difficult to repair. It is therefore necessary that this database contains reliable data, especially as far as cadastral parcels are concerned, which would describe these parcels in a way that reflects their actual state, resulting from the documentation submitted to the authorities responsible for keeping the register of land and buildings, i.e. district governors and presidents of large cities with county rights. It is extremely unacceptable when the law itself that incorrectly regulates the procedure of capturing and recording cadastral data is the source of discrepancies and legal defects. Unfortunately, this is the case with the procedure of the restoration of boundary markers and determination of boundary points, as well as with the method of recording data on the course of parcel boundaries in the cadastral survey of the register of land and buildings, whose main element is the EGiB database. The problem has been discussed in numerous articles in surveying magazines [4-7], book studies [8-10] and included in the decisions of administrative courts [11-13].

\section{Materials and Methods}

Before 1 January 1999, Article 39 of the Geodetic and Cartographic Law only allowed the restoration of boundary markers (boundary points monumented on the ground), whose location had previously been determined as a result of real 
property delimitation. After section 5 was added to Article 39 of the Geodetic and Cartographic Law on 1 January 1999 [1, 14] with the following wording: "The provisions of sections 1-4 shall be applied accordingly in the determination of boundary points previously entered into the register of land and buildings", it also became possible to establish the boundary points determined as a result of real estate delimitation proceedings, which had not been previously demarcated with boundary markers, as allowed in exceptional cases by the secondary legislation to the Geodetic and Cartographic Law regarding real estate delimitation $[15,16]$. The unfortunate wording included in the added section 5: "previously entered into the register of land and buildings", enabled various, often divergent, interpretations and methods of applying the legal provisions discussed in this article. The very possibility of the determination of boundary points, and not just the restoration of boundary markers, was undoubtedly needed and expected by property owners, but the method of regulating this procedure in the regulations of the Geodetic and Cartographic Law in the chapter on real estate delimitation has caused and continues to cause numerous problems. They became even more apparent after the introduction of the Regulation on the register of land and buildings on 2 June 2001, which defined the method of entering boundary points into the EGiB database as well as the list and the values of their attributes [3]. The situation has not improved by the subsequent amendments to this law introduced in 2013 and 2016, as not only did they fail to provide a clear identification of the origin of the coordinates of boundary points but also complicated them. The meanings of individual attributes have been changed without changing or adding new values [17-19]. Such a situation negatively affects the quality and reliability of the EGiB database and, in the view of the author, requires urgent and in-depth changes.

\section{Proposed Amendments to Legal Regulations}

In order to eliminate the existing contradictions and ambiguities in the provisions of the Geodetic and Cartographic Law regarding the boundary points of cadastral parcels and to meet the legitimate demands and expectations of property owners, the author proposes the introduction of several amendments to the existing regulations [3, 15]. These include, first of all, changes in ordering and supplementing the glossary of the terms used by the Geodetic and Cartographic Law, so that there is no need, as is currently the case, to use terms that have not been defined, or defined only in the secondary legislation to the Act.

In order to ensure the clarity and correctness of legal provisions, it is proposed to transfer the somewhat revised definitions of a boundary point and a boundary marker from [15] to the Geodetic and Cartographic Law (the so-called glossary of the Act). 
Then, the new clauses numbered $5 \mathrm{a}$ and $5 \mathrm{~b}$ would have the following wording:

Art. 2. Whenever the Act refers to:

5a) the boundary point - it shall be understood as the point determining the course of the boundary of the cadastral parcel;

5b) the boundary marker - it shall be understood as a marker made from durable material placed at the boundary point or a permanent element of land development located in this point, as well as a marker referred to in Article 31 section $2 b^{3}$;

The proposed points $5 \mathrm{a}$ and $5 \mathrm{~b}$ do not refer to the turn point of the property boundary as in [15], but the boundary of the cadastral parcel, which allows to expand the meaning and applicability of this term and to reconcile the requirements of the provisions on the register of land and buildings with the provisions on real estate delimitation. As far as the definition of the boundary marker is concerned, a reference to the proposed new entry in Article 31 of the Geodetic and Cartographic Law was added, which, according to the Author, should be supplemented with sections $2 a$ and $2 b$, based almost exactly on the entries previously made in [15] which read as follows:

2a. Boundary markers shall be placed at the turn points of the boundaries, at a distance of good visibility from one point to another, at intervals of no more than $200 \mathrm{~m}$.

$2 \mathrm{~b}$. In the case of natural, irregular or inaccessible boundaries, boundary markers shall be placed at or near the main turn points of the boundary, while providing the data that would allow for the determination of all boundary points.

Therefore, as proposed above, in justified, exceptional cases, the boundary marker may be placed not exactly at the boundary point, but in its vicinity. As a result of the introduction of this amendment to the Geodetic and Cartographic Law, the definition of an unmonumented turn point would also be legally sanctioned, which currently exists in [15] with regard to the real estate delimitation procedure. The added entry about inaccessible boundaries applies e.g. to boundary points located under buildings or other building structures.

According to the author of this research paper, the glossary of the Geodetic and Cartographic Law should also include the definition of the cadastral parcel and the definition of the boundary of the cadastral parcel, transferred from [3], which should read as follows:

8c) the cadastral parcel - it shall be understood as a continuous area of land, located within one cadastral unit, homogeneous in legal terms, parcelled out from the surroundings by means of boundaries;

8d) the boundary of the cadastral parcel - it shall be understood as part of the perimeter of the cadastral parcel, in the form of a section or sections based on boundary points common for at least two neighbouring cadastral parcels or points overlapping with the points of the state border - in the case of the cadastral parcels adjacent to this border;

For the definition of the boundary of the cadastral parcel, it is necessary to introduce an amendment that sections of the parcel boundary should be based on "boundary points shared by at least two neighbouring cadastral parcels" rather than, as currently stated, "shared by two neighbouring cadastral parcels". This

\footnotetext{
3 All the distinctions in the quotations were introduced by the author.
} 
amendment is necessary due to legal and technological requirements as well as the occurrence of some serious problems described in more detail in [18, 19].

The provisions of $\S 36$ regarding the data source on the course of parcel boundaries should be transferred from [3], with an amendment consisting of deleting the studies on the course of the state boundaries as a source of data, drawn up by the National Border Protection Authorities supervising state borders. The content of the proposed Article 24c, which should be included in the Geodetic and Cartographic Law in the chapter on the register of land and buildings, shall read as follows:

Art. 24c 1. The course of the boundaries of cadastral parcels is entered into the records based on the surveying documentation adopted for the database of the National Geodetic and Cartographic Documentation Centre, drawn up:

1) in delimitation proceedings;

2) for the purpose of real estate subdivision;

3) in land consolidation and exchange proceedings;

4) in real estate consolidation and subdivision proceedings;

5) for the purposes of court or administrative proceedings, and then used to issue a final court decision or final administrative decision;

6) for establishing the real estate cadastre and the register of lands and buildings based on the previously applicable regulations;

7) as a result of the restoration of boundary markers or the determination of boundary points;

8) as a result of establishing the course of the boundaries carried out under Article 24d.

The acquisition of data from surveys establishing the course of boundaries, currently being carried out in the so-called cadastral mode provided for in \$§37-39 of the Regulation [3], have been added in clause 8. This mode should be transferred to the Geodetic and Cartographic Law, to Article 24d with necessary amendments, which due to their size and nature have not become the subject of this research paper but have been partly discussed in [19].

Article 39, regarding the restoration of boundary markers and determination of boundary points, currently contained in the chapter on real estate delimitation, should be deleted from the Geodetic and Cartographic Law, and its modified content should be moved to the section on the register of land and buildings, to the above-proposed new Article 24c, with the following wording:

2. The boundary markers that have been moved, damaged or destroyed, the position of which is specified in the documentation referred to in section 1 clauses $1-8$, can be restored if there are reliable data allowing to determine their original position with the required accuracy.

3. The provisions of section 2 shall apply accordingly to the determination of boundary points whose location is specified in the surveying documentation referred to in section 1 clauses 1-8.

4. If, however, a dispute arises as to the position of the restored boundary markers or determined boundary points, the parties may request the dispute to be resolved by the relevant authorities.

5. The restoration of boundary markers or the determination of boundary points shall be performed at the request of the entities referred to in Article 11.

6. The entities referred to in Article 20 section 2 clause 1 shall be notified about the restoration of boundary markers or the determination of boundary points. To such notifications, the provisions of Article 32 sections 1-4 shall apply.

The proposed amendments were initially prepared by the author of this research paper in October 2018 at the request of the chairman of the "Team for the 
Assessment of Legal Regulations Related to the Operation of the Register of Land and Buildings", appointed on 10 July 2018 by Waldemar Izdebski - the Surveyor General of Poland [20]. The content of the amendments presented above also includes the suggestions and corrections submitted by some members of this Team.

Following the above proposals, it is necessary to change the application scheme in [3] regarding the database of the register of land and buildings. This scheme e.g. includes a class (object) named "EGB_Punkt_Graniczny" regarding the boundary point, whose one of the attributes is "ZRD" - object location data source [3]. It is proposed to change the scope (list) of values that the ZRD attribute of the boundary point may assume, so that the information acquired by the user based on this attribute, as is frequently the case today, would not lead to a system (official) reduction in the reliability of the EGiB data by blurring and distorting the attribute values of the points saved in it. The changes proposed in [18] include a list of the ZRD values extended with the following values:

- 107 - for field surveys preceded by the restoration of boundary markers,

- 108 - for field surveys preceded by the determination of boundary points.

The values of 107 and 108, which are a more detailed specification of the ZRD value of " 1 ", should be reserved for the restoration of boundary markers or the determination of boundary points, carried out based exclusively on the boundary delimitation documentation, and thus having the validity of delimitation. If the restoration or determination of boundary points is performed based on other materials, such as approved real estate subdivision projects or consolidation and subdivision projects, an additional attribute should be added to the EGiB application scheme, for example named "ZRDP", which is an extension of the current ZRD attribute that can assume at least two values: the first one concerns the "original" coordinates captured directly from the subdivision survey or consolidation and subdivision survey, and the second one relates to the coordinates captured as a result of the restoration of boundary markers or determination of boundary points carried out based on the approved real estate subdivision projects or consolidation and subdivision projects (Tab. 1).

Table 1. An example of a proposed method of extending

the permissible values of the ZRD attribute based on the example of the value " 5 "

(approved real estate subdivision projects or consolidation and subdivision projects)

\begin{tabular}{||c|c|l||}
\hline $\begin{array}{c}\text { ZRD } \\
\text { Attribute }\end{array}$ & $\begin{array}{c}\text { ZRDP } \\
\text { Attribute }\end{array}$ & \multicolumn{1}{|c|}{ Description of the attribute value } \\
\hline \hline \multirow{3}{*}{5} & 501 & $\begin{array}{l}\text { Approved real estate subdivision projects or consolidation and subdivision } \\
\text { projects } \\
\text { projects }\end{array}$ \\
\cline { 2 - 3 } & 502 & $\begin{array}{l}\text { Geodetic field surveys preceded by the restoration of boundary markers or } \\
\text { the determination of boundary points carried out based on the approved } \\
\text { real estate subdivision projects or consolidation and subdivision projects }\end{array}$ \\
\cline { 2 - 3 }
\end{tabular}


It might be the case, however, that the coordinates of the points captured as a result of the plane land survey of restored boundary markers or determined boundary points will significantly differ from the source (original) coordinates, e.g. due to the surveying methods used (such as satellite GNSS surveys) which are much more accurate than those used for the "original" surveys [21].

It is also necessary to transfer all methods for "determining" the location of boundary points in the so-called cadastral mode, i.e. under the current $\S 39$ of the Regulation on the register of land and buildings [3], to the new ZRD group with a value of " 10 ". The author has deliberately not used the above term "determination", because the current content of these provisions, which undoubtedly requires significant amendments, allows the surveyor (it is the surveyor who "determines" the course of the boundaries) to identify the course of the boundary subject to plane land survey based on hierarchically defined criteria, which are (in short):

1. Consistent indications of the eligible entities of the register of land and buildings ( $\$ 39$ section 1 of the Regulation [3]).

2. The last peaceable possession ( $\$ 39$ section 2 of the Regulation [3]).

3. Analysis of all available materials ( $\$ 39$ section 3 of the Regulation [3]).

Table 2 presents the proposed additional values of the ZRD attribute.

Table 2. A proposed method of extending the permissible values of the ZRD attribute for the cases of determining coordinates of points under the provisions of the Regulation on the register of land and buildings

\begin{tabular}{|c|c|c|}
\hline $\begin{array}{l}\text { ZRD } \\
\text { Attribute }\end{array}$ & $\begin{array}{l}\text { ZRDP } \\
\text { Attribute }\end{array}$ & Description of the attribute value \\
\hline \multirow{7}{*}{10} & & $\begin{array}{l}\text { Determining coordinates of boundary points of cadastral parcels under } \\
\text { the provisions of the Regulation on the register of land and buildings }\end{array}$ \\
\hline & 1001 & $\begin{array}{l}\text { Geodetic field surveys preceded by determining the position of points } \\
\text { under } \$ 39 \text { section } 1 \text { of the Regulation [3] }\end{array}$ \\
\hline & 1002 & $\begin{array}{l}\text { Geodetic field surveys preceded by the restoration of boundary markers } \\
\text { or the determination of boundary points based on ZRDP } 1001\end{array}$ \\
\hline & 1003 & $\begin{array}{l}\text { Geodetic field surveys preceded by determining the position of points } \\
\text { under } \$ 39 \text { section } 2 \text { of the Regulation [3] }\end{array}$ \\
\hline & 1004 & $\begin{array}{l}\text { Geodetic field surveys preceded by the restoration of boundary markers } \\
\text { or the determination of boundary points based on ZRDP } 1003\end{array}$ \\
\hline & 1005 & $\begin{array}{l}\text { Geodetic field surveys preceded by determining the position of points } \\
\text { under } \$ 39 \text { section } 3 \text { of the Regulation [3] }\end{array}$ \\
\hline & 1006 & $\begin{array}{l}\text { Geodetic field surveys preceded by the restoration of boundary markers } \\
\text { or the determination of boundary points based on ZRDP } 1005\end{array}$ \\
\hline
\end{tabular}

The boundary points, whose position is specified in the Regulation on the register of land and buildings, should have the currently assigned values of the ZRD attribute of " 1 " or " 9 " changed (revised), by adjusting them to the values presented 
in Table 2. This will allow the unambiguous identification of these points in the EGiB database and systematizing the ZRD attribute for the values of " 1 " and " 9 " in order to protect the user from being misled.

The proposed solutions will allow the restoration of boundary markers and the determination of boundary points based on the relevant surveying materials contained in the database of the National Geodetic and Cartographic Documentation Centre (PZGiK), originating from various geodetic and legal studies and not only from delimitation proceedings, but maintaining reliable information about the actual source of data (e.g. linear measurements, coordinates) that have been used for this purpose.

\section{Conclusions}

The current legal regulations regarding the restoration of boundary markers and the determination of boundary points not only fail to explicitly answer the question of when such technical and substantive procedures can be performed, but do not allow unambiguous, user-readable attributes to be assigned to the boundary points in the database of the register of land and buildings, either.

The purpose of the proposed amendments to be introduced in the Geodetic and Cartographic Law and in the Regulations on the register of land and buildings [3] as well as on the real estate delimitation [15] is both the clarification and harmonization of the procedure of the restoration of boundary markers and the determination of boundary points, as well as enabling a reliable way of entering the data on the attributes of boundary points describing the boundaries of cadastral parcels into the EGiB database. As a result, it is intended to foster a gradual increase in the reliability of EGiB data and the implementation of legitimate postulates and expectations of the users of the cadastral data, who want to enjoy the possibility of the efficient determination of the boundaries of their cadastral parcels on the ground.

\section{References}

[1] Ustawa z dnia 17 maja 1989 r. Prawo geodezyjne i kartograficzne. Tekst jednolity: Dz.U. 2019 poz. 725 z późn. zm. [Act of 17 May 1989 Geodetic and Cartographic Law. Consolidated text: Journal of Laws of 2017 item 2101 as amended].

[2] Rozporzadzenie Ministra Spraw Wewnętrznych i Administracji z dnia 9 listopada 2011 r. w sprawie standardów technicznych wykonywania geodezyjnych pomiarów sytuacyjnych i wysokościowych oraz opracowywania i przekazywania wyników tych pomiarów do państwowego zasobu geodezyjnego i kartograficznego. Dz.U. 2011 nr 263, poz. 1572 [Regulation of the Minister of Internal Affairs and Administration of 9 November 2011 on technical standards for the performance of plane and vertical land surveys as well as elaboration and transfer of the results to the national geodetic and cartographic resource. Journal of Laws of 2011 No. 263, item 1572]. 
[3] Rozporzadzenie Ministra Rozwoju Regionalnego i Budownictwa z dnia 29 marca 2001 r. w sprawie ewidencji gruntów i budynków. Tekst jednolity: Dz.U. 2019 poz. 393 [Regulation of the Minister of Regional Development and Construction of 29 March 2001 on the register of land and buildings. Consolidated text: Journal of Laws of 2019, item 393].

[4] Felcenloben D.: Dopuszczalność wznowienia znaków i wyznaczania punktów granicznych w trybie art. 39 Prawa geodezyjnego i kartograficznego [Permissibility of resuming border signs and determining border points in the mode of art. 39 of Geodetic and Cartographic Law]. Przegląd Geodezyjny, R. 90, nr 2, 2018, pp. 17-23.

[5] Hycner R., Wiśniewska A.: Przypadek sporu przy wznawianiu znaków granicznych nieruchomości [The case of dispute during resuming boundary marks of possessions]. Acta Scientifica Academiae Ostroviensis, no. 1, 2013 pp. 413-432, http://zn.wsbip.edu.pl/wydania/zeszyt2/sekcjaA/22.PDF [access: 17.05.2019].

[6] Pietrzak L.: Stabilizacja granic w pracach geodezyjnych [Stabilization of parcel boundaries in geodetic surveys]. Przegląd Geodezyjny, R. 90, nr 7, 2018, pp. 18-23.

[7] Radzio W.: Ad vocem do niektórych tez dr inż. Dariusza Felcenlobena [Ad vocem to some theses of Dariusz Felcenloben, PhD, Eng.]. Przegląd Geodezyjny, R. 90, nr 4, 2018, pp. 16-18.

[8] Felcenloben D.: Granice nieruchomości i sposoby ich ustalania. LexisNexis, Warszawa 2011.

[9] Kwartnik-Pruc A., Hanus P.: Geodezyjne aspekty rozgraniczeń i podziałów nieruchomości. Wydawnictwa AGH, Kraków 2014.

[10] Wolanin M.: Podziały, scalenia i rozgraniczenia nieruchomości oraz procedury ewidencyjne. C.H. Beck, Warszawa 2016.

[11] Wyrok NSA z 25.10.2018 r. Nr I OSK 2819/16 [Judgement of the Supreme Administrative Court of 25.10.2018 Ref. No. I OSK 2819/16], http://orzeczenia.nsa.gov.pl/doc/AE46AB8EF0 [access: 17.05.2019].

[12] Wyrok WSA z 28.09.2017 r. Nr III SA/Gd 480/17 [Judgement of the Provincial Administrative Court in Gdansk of 28.09.2017 Ref. No. III SA/Gd 480/17], http://orzeczenia.nsa.gov.pl/doc/CD20C85B80 [access: 17.05.2019].

[13] Wyrok WSA z 30.08.2018r. Nr III SA/Kr 319/18 [Judgement of the Provincial Administrative Court in Krakow of 30.08.2018 Ref. No. III SA/Kr 319/18], http://orzeczenia.nsa.gov.pl/doc/EBFCF4E4EB [access: 17.05.2019].

[14] Ustawa z dnia 24 lipca 1998 r. o zmianie niektórych ustaw określajacych kompetencje organów administracji publicznej - w zwiazku z reforma ustrojowa państwa. Dz.U. 1998 r. nr 106, poz. 668 [Act of 24 July 1998 amending certain acts specifying the competences of public administration bodies - related to the systemic reform of the state. Journal of Laws of 1998 No. 106, item 668].

[15] Rozporzadzenie Ministrów Spraw Wewnętrznych i Administracji oraz Rolnictwa i Gospodarki Żywnościowej z dnia 14 kwietnia 1999 r. w sprawie rozgraniczania nieruchomości. Dz.U. 1999 nr 45, poz. 453 [Regulation of the Ministers of Internal Affairs and Administration as well as Agriculture and Food Economy of 14 April 1999 on real estate delimitation. Journal of Laws of 1999 No. 45, item 453]. 
[16] Zarzadzenie Ministrów Gospodarki Przestrzennej i Budownictwa oraz Rolnictwa i Gospodarki Żywnościowej z dnia 5 sierpnia 1996 r. w sprawie rozgraniczania nieruchomości. M.P. 1996 nr 50, poz. 469 [Ordinance of the Ministers of Spatial Management and Construction as well as Agriculture and Food Economy of $5 \mathrm{Au}$ gust 1996 on real estate delimitation. Official Journal of 1996 No. 50, item 469].

[17] Hanus P., Pęska-Siwik A.: Punkt graniczny i źródło danych o jego położeniu (atrybut ZRD) [The boundary point and source of data about its location (attribute ZRD)]. Przegląd Geodezyjny, R. 90, nr 8, 2018, pp. 14-18.

[18] Maślanka J.: Determining the course of boundaries based on points shared by several properties and entering this data into the register of land and buildings. Infrastruktura i Ekologia Terenów, nr IV/1/2018, pp. 879-890.

[19] Maślanka J.: Ustalanie przebiegu granic działek ewidencyjnych w trybie przepisów o ewidencji gruntów i budynków oraz wykazywanie ustalonych granic w bazach ewidencyjnych - wybrane aspekty formalno-prawne i technologiczne [Determining the course of the boundaries of cadastral parcels pursuant to the provisions on the register of land and buildings and entering the determined boundaries into cadastral databases - selected formal, legal and technical aspects]. Infrastruktura i Ekologia Terenów Wiejskich, nr III/1, 2018, pp. 741-754.

[20] Główny Urząd Geodezji i Kartografii: Powołanie Zespołu do Oceny Regulacji Prawnych Zwiąanych z Funkcjonowaniem Ewidencji Gruntów i Budynków. 10 July 2018, http://www.gugik.gov.pl/aktualnosci/2019/10.07.2018-powolanie-zespolu-do-oceny-regulacji-prawnych-zwiazanych-z-funkcjonowaniem-ewidencji-gruntow-i-budynkow [access: 20.05.2019].

[21] Maślanka J., Latoś S.: Analiza dokładności map numerycznych i cyfrowych [Accuracy analysis of numerical and digital maps]. Geodezja - Akademia Górniczo-Hutnicza im. Stanisława Staszica w Krakowie, t. 6, z. 2, 1998, pp. 163-177.

\section{Wznawianie znaków granicznych i wyznaczanie punktów granicznych - propozycje zmian w przepisach polskiego prawa}

Streszczenie: Artykuł przedstawia propozycje zmian w przepisach polskiego prawa geodezyjnego i kartograficznego dotyczących wznawiania znaków granicznych i wyznaczania punktów granicznych działek ewidencji gruntów i budynków. Obecnie obowiązujące w tym zakresie uregulowania prawne są nie tylko niewystarczające, ale też niejednoznaczne, co prowadzi do występowania znacznych i szkodliwych rozbieżności zarówno w zakresie interpretowania przepisów prawa, jak i ich stosowania. W wyniku takiej sytuacji baza danych ewidencji gruntów i budynków (EGiB), rejestrująca między innymi informacje o przebiegu granic działek ewidencyjnych oraz o atrybutach punktów granicznych opisujących te granice, nie odpowiada dosyć często rzeczywistości, 
a zatem jest niewiarygodna. Ze względu na duże znaczenie tych danych i samej bazy EGiB w systemie społeczno-gospodarczym państwa, taki stan nie powinien być dłużej tolerowany. Autor wskazuje w artykule na problemy zarówno w zakresie regulacji prawnych dotyczących samej procedury, jak i treści bazy danych EGiB. Wady występujące w jednym i w drugim zakresie niosą bowiem równie istotne, negatywne konsekwencje dla jakości danych EGiB i przyczyniają się do utraty ich wiarygodności. Przedstawione w artykule propozycje konkretnych zmian w przepisach prawa mają zapobiec dalszemu błędnemu interpretowaniu i stosowaniu obecnych przepisów prawa oraz mają pozwolić na spełnienie uzasadnionych oczekiwań i potrzeb użytkowników danych EGiB, w tym w szczególności właścicieli nieruchomości.

\section{Słowa}

kluczowe: kataster, ewidencja gruntów i budynków, granice działek ewidencyjnych, punkty graniczne działek 